\title{
Traditional rulers and security administration in Nigeria: Challenges for the $21^{\text {st }}$ century
}

\author{
Uthman Abdullahi Abdulqadir \\ Department of Sociology, Faculty of Social Sciences, Usmanu Danfodiyo University, Sokoto, Nigeria
}

\begin{abstract}
The central concern of this paper is to examine the major roles of traditional rulers in security administration in Nigeria and the challenges facing the social order, peace and stability of the people as we are just a few decades in the millennium i.e. the $21^{\text {st }}$ century. This paper hopes to significantly contribute toward new researches in this direction. The legacies of traditional authority of the Sokoto Sultanate and Nigeria in general, (though its roles are changing) have been affecting the modern rational authority of contemporary politics and the entire administration of criminal justice system in Nigeria. The main task of the paper is to identify the roles they play and the challenges inhibiting the efficient security administration in contemporary Nigeria. The adaptive changing patterns and roles are as a result of several factors: A pre-colonial, colonial and post-colonial change in the institution has affected the social order and adjudication of criminal justice system. Also, the dependency or interrelationships of both the government of the State will be shown as a concurrent determinant of the inter-relationship between the traditional rulers and contemporary security administration in Nigeria. Also, in examining the changes the traditional institutions have undergone in their conservative roles and how they have affected contemporary security situations in the country. The paper sees what influence has the traditional rulers have in shaping the structure and function of the modern security in Nigeria. In achieving this, the paper basically adopts content analysis and found that despite the roles the traditional rulers play in security administration, they are faced with numerous challenges, which include constitutional impediment, lack of proper roles as advisory etc. Based on this, the paper recommends that the constitution should stipulate clearly what their roles are.
\end{abstract}

Keywords: Traditional rulers, challenges, security, roles, administration

\section{INTRODUCTION}

It is important to concede that the area of the study has attracted the minds of various scholars and researchers. Yet it is the concern of this study to examine and relate such research endeavors on traditional authority to the contemporary security challenges in Nigeria. The exact nature and patterns of governancecum, socio-economic inter-relationship between the traditional rulers and contemporary security situations will improve our understanding of the criminal justice system specifically in resolving issues of socio-political insecurity and religious conflicts thereby restoring social order, peace, harmony and stability. The general objective of the paper is to examine the role of traditional rulers in security administration from pre 1804 period, 1804-1903, 1903-1960 and 1960 and beyond; identify the structures, institutions as well as social changes on contemporary security in Nigeria. This is done by comparing roles of leadership of traditional rulers. The study will significantly contribute towards research efforts to dispute the claim. The findings of this research hopefully will put the roles and legacies of the traditional rulers into proper perspective to bear on the contemporary security situation/matter in Nigeria.

\section{CONCEPTUAL ISSUES}

Security as a basic human need is important to the individual community. According to Alemika (2015) security is a contested concept, it means different things to different people and it also a contested practice, security for a group may constitute insecurity for another group. Therefore, security raises ontological debates about its nature and scope. Is there such a thing as security? There are two perspectives on the ontology or reality of security. The first perspective argues that security depicts a reality, a feeling and a condition. The second perspective conceives security as a label attached to a condition that someone considers undeniable. Balogun (2004:1) observed that man's primary and engaging concern has been that of survival and protection; from the vagaries of nature, natural disasters and from the ill-intentions and misdeeds of his fellow man. community 


\section{TRADITIONAL INSTITUTIONS}

By traditional institutions, it refers to the indigenous political system or arrangements whereby leaders with proven track of records are nominated, appointed and installed in accordance with the provisions of their native laws and customs (Malami, 1978, Orji and Olali, 2010). The essence of the institutions is to preserve the customs, traditions and cultural heritage of the people and manage conflicts and violence arising among or between members of the community by the instrumentality of laws and customs of the people.

\section{TRADITIONAL RULERS}

In our day to day language we often hear the word traditional rulers in our society. The concept refers to the indigenous arrangements whereby leaders or persons by virtue of heredity or people with proven track records are nominated, appointed and installed in line with the provisions of their native laws and customs. The essence of the institution is to preserve the tradition, the customs, cultural heritage of the people and to manage, settle and resolve disputes/conflict arising within or between members of the community by the instrumentality of laws and customs of the people in that particular community or society. Generally, they are seen and referred to as the custodians of their people's norms, cultural values and practices. Adding on conceptual clarifications, Malami (1978:11) has identified three categories of traditional title holders that derive their titles from and through the traditions of the people, although the traditions vary from time, place and depth of cultural roots.

Firstly, those holding literally honorific titles, conferred on them by superior traditional rulers in recognition and appreciation of the service rendered to the society. This category has no schedules or specific functions seen as a good chain of information and agents of conscientizing or mobilizing people when the need arises. The second category are holders of titles or positions due to recent recognition or creation of such titles. In contrast to the above, they may have executive functions but restricted by the same laws that created them or gave them recognition. The last category is full time executive traditional title holders who perform executive functions from traditions largely rooted, revered and recognized and exercise their executive functions.

\section{ROLES OF TRADITIONAL RULERS IN SECURITY ADMINISTRATION IN NIGERIA}

Traditional rulers hold the key to the success or failure in security administration in Nigeria because they operate at the grassroots of the society and interact closely with people in their daily activities consequent upon which they are highly respected. Abdullahi (2008) noted;

Community based approach as opinion leaders' traditional authority are first stakeholders if they do not back opinion will face problem as they are closer always in contact with people.

Traditional rulers' specified roles in security maintenance include the following:

(1) Membership of emirate, district, village and ward security; observation, surveillance and maintenance and the weekly meeting

(2) Security of village, ward, district and emirate vigilante committees

(3) Security surveillance reports pass to relevant authorities.

(4) Head of urban and rural areas, security watchdogs and reporters to know about happenings every minutes, seconds, hours, time, days, weeks, months and years.

(5) Security ICT Networking with CCTV Cameras and gadgets

(6) Head of security, safety and protection enlightenment campaigns

(7) Sensitizing/conscientizing individuals. What citizens need to know i.e. do and don'ts on security tips in form of vigilance, surveillance etc.

(8) Meetings attendants

(9) Policy decision making

(10) Making security surveillance and intelligence reports.

(11) Watchdogs in numbering all houses to know their occupants and their general conduct (Orji and Olali, 2010:402).

\section{THEORETICAL EXPLANATIONS}

This paper has adopted the following as combined theoretical framework of analysis. The security and defence outfit in Nigeria has been shaped and formed by the colonialists. Of-course, prior to their coming, both the state and the royal institutions had their Dogarai system and this later operated under the Native Authority (NA) in both the colonial and post-colonial eras. It is the aim to protect the people's lives and properties that those saddled with the management of the political apparatus of the state had to create the security outfit. Thus, the entire Criminal Justice System, or agencies were meant to ensure security for the state, punish offenders, and 
coerce the ordinary people into compliance with the will of the political authority or the state. The criminal justice system was also meant to define, protect and apprehend suspects or criminals. In the discharge of their duties, they are supposed to be neutral arbiters, apolitical and benevolent seen as friends for development. Instead, they beoame agents of oppression; exploitation and coercion. This affects the security-public relations. Security agencies are seen by the general public as politically siding with the government of the day as they always maintain the notion that, it is the order from the above, instead of them to serve as a referee between people, people and government instead of serving the interest of the people and the state by making the general public to conform and comply with the aspirations, expectations of the citizenry, they rather protect the dominant ruling class in the society. These in all sense posed a serious challenge to the security administration in the $21^{\text {st }}$ century.

\section{HIERARCHY OF NEEDS THEORY}

Security is a basis (human needs), it is a basic truth for an individual group, society, organism, an organization to survive, certain conditions necessary. Need is therefore an absolute a precondition, pre-requisite for survival and whose death, disintegration, demise, collapse etc. will follow (Muhammad-Baba, 2012). American psychologist, Abraham Maslow (1948), articulated the hierarchy of needs. To him the survival of the human being whether for the individual or humanity as a whole of the personal or group level is dependent on the fulfillment of certain needs or necessities, at least one of which is fundamental and physiological (biological) such as food, shelter and clothing. Other needs on which survival depends include security, sense or experience of love, care, affection and belonging, self-esteem, respect and self-actualization or the realization of one's potential(s).

In order to meet the need for survival in the society, people look up to the traditional institutions to provide security for their lives and property. In Hausaland and most African societies, traditional head is the custodian of all spheres of life. There is well-organized chain of command and authority which ensure that chief or village head is aware of entry and exist of all his subjects even in peace time (Abdullahi, 2005). The people submitted themselves and were absolutely submissive to the authority of the rulers who in turn were expected to rule for the general good and welfare of the community as a whole. They were seen as the symbols of the people's past, present, custodians of their history, upholders and preservers of their security culture and customs, epitome of cultural norms and values of the society such as truth, discipline, courage and responsibility and so on.

Maslow (1958) in his theory of motivation on hierarchy of human needs sees security as one of the basic human needs that is very vital to the individual community. Marx Weber a key figure in the discussion of traditional authority. Weber analyzed traditional authority as deriving from traditional ways of divine rights of kings. It is a legitimate decision of power under the traditional authority. The power types derive from the sociological recognition accorded incumbents who have been involved in struggles for power, influence and authority, that is in order to rule, govern, lead or manage the people in their social, political and economic activities for development.

Rational legal authority is rational in terms of whatever the organizational goals of a society are; and which can be achieved through roles played. Through the rational criteria the society allocates or others allocate to themselves, the leadership or authority to certain people to implement the rules and laws for management and control of people for effective leadership and followership.

\section{DEPENDENCY THEORY}

Dependency theory in this regard, is apt in trying to explain the challenges militating against the traditional institutions of governance from living up to their expectations, traditional responsibilities of security administration conflict management and resolution as was obtainable before the advent of colonialism (Abdullahi, 2005). The theory is of the view that Africa and indeed Nigeria's underdevelopment and by extension the failure of institutions like the traditional institutions was as a result of the integration and incorporation of the continent and indeed the country into the periphery of global capitalist system to play subservient role to international capital. The proponents of the theory Gunder Frank, Fanon, Rodney etc. have argued that the issue that bother on the failure of Africa as a continent and Nigeria as a country can only be explained within the context of bourgeoisie hangover of colonialism and imperialism. An extrapolation of classical Marxist theory, dependency theory is exposed in the works of Lenin, Luxemburg in 1910's and 1920's and later developed by American and African scholars like Gunder, Frank, Samir Amen, Fanon, Rodney among others. Lenin and Luxemburg have argued that, what today is known as underdeveloped countries can only be explained within the framework of the influences on production relations and capital formation process in the so-called 'advanced world'. This theory was propounded by Third World Scholars and put together in the Sixties by eminent writers such as Luxemburg (1964), Frank (1969), Santo (1970), Cock Roft et al (1972), 
Rodney (1972), Amen (1976), Cardosso and Far Letto (1979), Offong (1980), Ake (1981), Ndoh (1995) and the like.

Indeed, traditional rulers constituted the early opposition to the colonization of Nigeria during the period of legitimate trade of which followed the abolition of Atlantic slave trade. They saw the desire of the Europeans to take over the control of the commerce in their domains as an affront against traditions and as the custodians of peoples' custom, they rose to the occasion by challenging the European domination and control. Example of traditional rulers abound in this regards, they included Caliph Attahiru I of Sokoto Caliphate, Kosoko of Lagos, Jaja of Opobo and Nana Olomo of Itsekiri in the oil Rivers as well as Satiru Revolt by Satirawa in 1906 in Sokoto Sultanate. All these leaders were captured and deported to enable the Europeans control the commerce of the areas under them and puppets were appointed in their positions. This disposition and enthronement of traditional rulers by the European officials during the period was to have disastrous impact on traditional chieftaincy institutions in Nigeria.

\section{JIHAD}

The most imperative and viable change brought about by the 1804 Jihad was in the political institution. For the first time in Hausaland, a centralized structure of government integrating all the distinct Hausa Kingdoms within one single authority and uniform system of government in the form of emirate system was established under the new political arrangement. The central and co-ordinating authority was at Sokoto, where the Amir-al-Mu'minin (Commander of the Faithful) resided and ruled over the emirates through the Caliphate. Outside Sokoto there were the various spiritual traditional rulers under the supervision of the emirs. Most of those who became the Emirs were the Fulani flagbearers appointed by the Jihadists into the Jihad campaigns in their territories. They had become emirs after conquering the Hausa Kingdoms. These Emirs were all under the leadership of Sokoto and answerable to the Caliph, who appointed them and who also had the power to depose them.

Basically the system of government in the Sokoto Caliphate was based on Caliphateship obtained through ascribed status rather than achievements. Though the beginning of the Caliphate system started through achieved feat in Jihad's success. The Caliphate became an ascribed system as from 1817 with the passage of Sheikh Usmanu Danfodiyo who was succeeded by Sultan Muhammadu Bello. The Caliph is the supreme head of the Caliphate which was like a federation for the operation of the day-to-day administrative activities of the emirates. The Caliph and Emir of Gwandu controlled appointments, dismissals of the emirs and the settlement of inter-emirate disputes within the Caliphate. The Caliphate established relations with foreign states and was responsible for the overall defence of the whole Caliphate.

Upon all his sweeping powers, the Caliph did not rule alone; he was assisted by a hierarchy of titled officials known as Masu Sarauta (ruling royal family) particularly the Waziri (vizier, head of officials, prime minister of the Caliphate) who is responsible for important executive and ceremonial duties i.e. advising the Caliph on appointment to high offices, summoning councilors, meetings on various issues of rulership including the defence and security of the polity.

There were the Magajin Gari (Minister for Zamfara and Katagum) Magajin Rafi (Minister for Bauchi), The Galadiman Gari (Administrator of the Caliphate) and the Madawaki (Cavalry commander). Each of these officials was appointed by the Caliph and could be removed by him. Each had a specific function to perform in assisting the Caliph in his administration of the Caliphate. This council advised the Caliph on major issues and the Masu Sarauta formed the ruling aristocracy. But all the same, the Caliph was directly the authority over the administration of the Caliphate.

The Caliphate had also a systematic social justice system that could wipe out deviant criminal acts, it was said to have introduced changes with palpable worsening insecurity situations into the affairs of the defence fortified strong holds and set up military force in each station of the Caliphate.

\section{COLONIAL BASIS OF TRADITIONAL RULERS, 1903 - 1960}

This section will give an account of the colonial encounters with the traditional authority between 1903 - 1960; and an attempt will be made to establish and analyse their roles as affecting the adjudication of security in contemporary Nigeria.

The year 1903 witnessed the subjugation of Nigeria by the British imperialist. This marked a shift of power control from the Fulani ruling class to the British Colonial officers. In buttressing this Fredrick Lugard (1903) had this to say;

The Fulani in old times under Danfodiyo conquered this country they took the right to rule over it, to levy taxes, to depose kings and to create kings. They in turn have by defeat now lost their rule which has come into the hands of the British. All these things which I have said, the Fulani by conquest took the right 
to do has now passed to the British. Every Sultan and the Emirs and the principal officers of the state will be appointed by the High Commissioner throughout the country.

By this, the 1804 Jihadists lost virtually all their powers except that their subjects (people) strongly revered them due to their survival on their thrones instead of total annihilation and have been agitating to return the lost glory. The title of the Sultan of Sokoto replaced the Caliph Amir al-Muminin and the name of the Caliphate changed to the Sultanate. In his letter Lugard claimed;

I have found it necessary to depose both these Emirs and to replace troops near their respective cities to keep peace and protect the people.

Lugard went on to advance in his so-called liberation mission and this time to London: "those in London who did not support war in Northern Nigeria are ignorant of the situations. They did not know how corrupt the foreign Fulani became. They bought and sold their own citizens into slavery. They took bribe, they oppressed their people, and they mutilated their citizens. In Bida, Kontagora and other places, where the British forces seized power, those evils have already been stopped. Similarly, they will be stopped in Kano and Sokoto; once these places were occupied by the British".

After the conquest, the general pattern of authority has changed with Lugard (Governor-General) on top of the hierarchy, then the Resident, the Assistant Resident and followed by the Sultan of Sokoto below the ladder. Likewise, the installed Sultan was nothing but a titular head as Tibenderana (1976) once observed:

... whatever, political power Attahiru II the installed Sarkin Musulmi had to exercise was to be limited to the Sokoto emirate, as he no longer had any means to enforce command as Sarkin Musulmi Attahiru's position was to be honorified rather than functional.

In this arrangement all emirs were answerable to the Resident through his Assistant who was in-charge of the Emirates for the maintenance of law and order as well as exchange of government policies in the emirates. Because of this, they had no specific or functional power or authority of any kind. This indicated the seizure of all powers of the Sokoto Caliphate by the British. Again:

..... the authority and power to rule over the land which you have inherited from your ancestors the Fulani acquired by the edge of the sword are now acquired entirely in the government of His majesty.

This made Lugard to assume the position hitherto exampled by the Caliph. The power of the Caliph as head of spiritual and temporal affairs was settled by the British. In addition, direct loyalty to the British was a must for retention of office. Lugard added:

The government is appointing you Muhammed Attahiru as the Sarkin Musulmi and the Emir of Sokoto on the condition that you obey the authority of the English King and the order of his representative the Government.

The chieftaincy of colonial parlance was to designate these African administrative authorities recognized by the colonial government. For the Sokoto Caliphate which had a centralized form of authority, they manifested a different variety of chieftaincy. They manifested a mixed socio-cultural values of the conquered Fulani Jihadists. There was also the Hausa traditional system as well as that of the basic principles of the Qur'an transformed and established within the period of the Caliphate. The Caliphate lost most of its traditional values in the wake of the colonial administration. Crowder argues:

... whatever or whether they had fulfilled all the traditional pre-requisite for assumption of office that which would have allowed them to rule in pre-colonial times their rights to rule was determined by the colonial authorities.

The implication of these new roles is that rather than serve as custodians and upholders of the values of the Caliphate from which they had managed, the colonial institution could only do these: to serve the whims and caprices of the colonial administration. This explains why the colonial administration left the actual collection of taxes to the Sultanate. The village heads were appointed to collect taxes from the community within which they operated. The British officers had the task of supervision with the aid of Dogarai (local policemen) and others who were messengers of the Sultan. The imposition of taxation brought about disagreement between the people 
and the Sultanate. The Sultan and Emirs were in dilemma because it was assumed that emirs were the people who assessed and imposed the taxes on their people. Malami observed:

... with their policy of British colonial administration the chiefs were no more looked upon as custodians of culture and tradition and they have to serve the interest of the British government which had domineering and exploitative nature.

The traditional political setting in this institution was distorted giving way to British form of government/administration. The position given to the Caliphate at the expense of their traditional institutions made many of them to become more powerful than was possible for them in the traditional setting.

They had their finest hours when they were functioning as sole native authority. It was explicitly stated that in the colonial administration in Nigeria, the British created traditional rulers more to be delegates of the colonial governors (District Officers). Lugard had this to say to his representative in Northern Nigeria:

"they would do everything within their competence to make the colonial administration to look into the eyes of Northerners as though they are not the former operators of the abolished traditional authority.

He further added to Resident that the British established traditional rulers and they should be made to understand the fact that they had no right to their own power and place unless they were answerable to the British King. It became clear to the former operators of the Caliphate that they were to operate on a new and different governmental system; nearly all their functions under the former system were practically removed from them.

The Sultan had no right to appoint, discipline or remove any Emir as he himself was to be appointed and disciplined by the British as his stay in office also depended on how he obeyed the British colonists:

"Every Sultan and Emir and the principal officers of the state will be appointed by the High Commissioner throughout the country. When an Emirate or an office of the state became vacant, it will only be filled with the consent of the High Commissioner and the person chosen.... will hold the place on condition that he obeys the laws of the protectorate and the conditions of his appointment"

By this remark or speech, the total overthrow of the Sokoto Caliphate was almost come. Likewise, even traditional councilors were not left behind in the annexation by the British because all councilors except the Waziri, were relegated to district heads and posted out of Sokoto. By this, the Sultan lost all his powers, support and respect of his subject.

Through indirect rule, the British believed it was their task to maintain what was functional in the indigenous institution and assist them to develop on their own lines. The relationship now changed to that of an adviser, and consultation with the Emirs and Native Authority affairs more often than ideally it should. The Native Authorities were to continue functioning similarly representing the state and central legislature.

Birth (n.d ) has this to add:

Traditional rulers' representation contributes as channels of communication between the government and citizens to the maintenance of political system. The chiefs were agents or spokesmen, not of an indigenous central regime but of colonial government. The British had to delegate certain powers to the chiefs but within the prescribed limits and only at the level of the local administration.

Ikimi noted that British colonialism was not meant to support traditional rulers. The customs and traditions were not supported by the colonizers, since the institution was not tolerated by them. They were not allowed to govern their communities according to tradition as it was before. They were not allowed to function as before, because the British were interested in maintaining the emirates for their colonial gains.

The colonial Nigeria experienced the influx of the British. As the British do in any country they make colony. They employed indirect rule system in governing their colonies. The colonial era marked the beginning of the changing role of the traditional authority in the power structure of its communities. This intervention was primarily intended to serve and protect the then ailing political and economic interest of the British political 
power. Thus, Lugard specified the roles of the Traditional Rulers in the power structure of the Native Authority system of administration that:

a chief appointed under the Native Authority is constituted as the guardian of political order in the area to which he is appointed and is vested with power over all natives residing in that area.

Other ordinances formally gave powers already exercised by major emirs and chiefs before the British occupation. These include control over lands, power to arrest, detain, adjudicate as well as raise taxes and other revenues. Therefore, the ordinances in legal terms form the basis of the role of the Traditional Rulers during the colonial period. By this political arrangement, the rulers were integrated into the power structure of the colonial administration as:

there was no desire on the part of the British colonial government to impose on the people any theoretically suitable form of government but rather to evolve from their own institutions based on their habits of thoughts, prejudices and customs the best forms of rules best suited to them and adopted to meet the new conditions.

\section{Traditional Rulers and Security Administration in Contemporary Nigeria}

There is no gainsaying the fact that the traditional rulers occupy a strategic position in modern Nigeria. This position was substantially recognized by different communities even before the period of colonization. It is this importance that influenced the colonialists to use it in order to achieve their selfish motives. One singular characteristic of the traditional authority is the capacity to change, as the situations and conditions change. Despite the onerous task, responsibilities and leadership and guiding roles that the traditional authority is expected to provide, it performed certain functions which helped to restore order and stability in Nigeria. These functions include among others, link with the grassroots, intermediating, mobilizing and sensitizing people on policies and programmes of the government etc. It is important to realize that, it is because of the considerable power and authority over its subordinates and subjects as well as maintenance of peace and order, security in its territory, coupled with divine and religious roles, that they enjoy degree of respect, loyalty and legitimacy within their territories. There are hierarchy of village elders, ward heads, village heads and district heads who can resolve disputes. Besides, these, traditional rulers act as a linkage tool in the contemporary political system in the country. This is so because the structure of traditional administration is still favoured by the people and could well serve them. They act as an intermediary between the government and the governed, by the fact that the institution receives orders from the government for transmission to their societies. Traditional rulers mobilized people for the response of their society towards the carrying out of some civic and security responsibilities. In addition, it helped to security surveillance and demands of the people in a sort of input to the proper channel in the decision-making hierarchy.

Generally, traditional rulers have been seen as a factor unifying not only their communities but also the sub-region and even the nation as a whole. On several occasions, traditional rulers have been called to mediate in national conflicts. According to Civil Rights Congress, which monitors outbreaks of violence, over the past thirty years, Nigeria has experienced 670 ethno-religious crises, leading to 85,000 deaths and 10 million displaced people. These outbreaks of violence occurred in many parts of the country such as Kaduna, Lagos, Jos, Kano, Bauchi and Benue, Oyo, Taraba and Niger Delta region. To be able to play a more active role in mediating and resolving large-scale civil conflicts, the Northern Traditional Leaders Forum has since been set up with the Sultan of Sokoto as Chairman. They meet regularly to review the peace and security situation. Of note is that the prestige attached to the institution influences conflicts that result from competition among numerous and potentially eligible candidates and their supporters. Such conflict has the potential to polarize and destabilize communities. Traditional rulers have been playing the role of peace builders and stabilizing their communities (Cookey, et, at, 2010).

Cookey, et, al, (2010) argued that traditional rulers are perceived as assisting the government in maintaining law and order in the communities as well as promoting peaceful co-existence of people of different religious, ethnic and social backgrounds. The way of life of ordinary people in Nigeria is deeply rooted in their culture and traditional are central to maintaining their cultural values and traditions. They found that, the traditional rulers are more accessible to the ordinary people in times of need and problem than government officials and elected politicians. In addition, traditional rulers treat their people without discrimination. People generally trust their traditional rulers and respect (Cookey, et, at, 2010). It is with these we now move to the next issue of post-colonial basis of the traditional rulers and see the changes that took place. 


\section{TRADITIONAL RULERS AND SECURITY ADMINISTRATION IN CONTEMPORARY NIGERIA}

There is no gain saying the fact that the traditional rulers occupy a strategic position in modern Nigeria. This position was substantially recognized by different communities even before the period of colonization. It is this importance that influenced the colonialists to use it in order to achieve their selfish motives.

One singular characteristic of the traditional authority is the capacity to change, as the situations and conditions change. Despite the onerous task, responsibilities and leadership and guiding roles that the traditional authority is expected to provide, it performed certain functions which helped to restore order and stability in Nigeria. These functions include among others, link with the grassroots, intermediating, mobilizing and sensitizing people on policies and programmes of the government etc.

It is important to realize that, it is because of the considerable power and authority over its subordinates and subjects as well as maintenance of peace and order, security in its territory, coupled with divine and religious roles, that they enjoy degree of respect, loyalty and legitimacy within their territories. There are hierarchy of village elders, ward heads, village heads and district heads who can on to resolve disputes. Besides, these, traditional rulers act as a linkage tool in the contemporary political system in the country. This is so because the structure of traditional administrations is still favour by the people and could well serve them. They act as an intermediary between the government and the governed, by the fact that the institution receives orders from the government for transmission to their societies. Traditional rulers mobilized people for the response of their society towards the carrying out of some civic and security responsibilities. In addition, it helped to security surveillance and demands of the people in a sort of input to the proper channel in the decision-making hierarchy.

It is with these we now move to the next issue of post-colonial basis of the traditional rulers and it is to this we now form to see the changes.

\section{POST-COLONIAL BASIS OF THE TRADITIONAL AUTHORITY: CHALLENGES FOR THE $21^{\text {ST }}$ CENTURY}

There is no community in the world that achieves development, order and stability without defined norms and values embedded in its institutions and exercised by its leaders.

The Traditional Authority has managed to survive the onslaught of colonialism. Some reverend place in the new setting even though it seems that the contemporary politicians are only honouring them in the meantime, this is why the Traditional Authority found itself in the prestigious but wholly ceremonial house of chiefs. Some of them were given ministerial appointments without portfolios. Some were becoming influential even more than the politicians. However, the politicians still need(ed) the institution to get the co-operation and support to quell conflict and restore order and stability. The Traditional Rulers survived not because they were constitutionally recognized but based on their utility to the new political setting. Likewise, since the parliamentary system had allowed opposition, they had to seek the support of the traditional rulers so as to reduce the weight of opposition, provision of surveillance of people coming into their communities.

In addition, the state of local government reforms since independence undoubtedly in no small measure affected the roles of the traditional authority, not only in local government administration but of the whole societal officers. The coming of the military into Nigerian politics in 1966 ushered in a gradual reduction of the participatory role of traditional rulers in local government administration. Thus structural re-organizations were implemented in various parts of the country with a view to establish new set of objectives in local government structures actions and functions. The traditional rulers were used as tax collectors and seen as administrative links between the regime and the people. They were used for chancellorship positions of a few universities in Nigeria and very frequently used as informal arbitrators of national as well as regional conflicts.

As a matter of fact, the introduction a Federal Constitution in 1954 which brought an end to indirect rule as it was replaced with both new systems of local government supposed to be a turning point for the usurpation of traditional rulers' authority in Nigeria.

In Northern Nigeria the position of the Traditional Rulers from 1967-1972 was greatly undermined in the context of power and authority. The instruments of coercion the police, courts, prisons, were removed from its control. This action undermined the Emir's legal power and authority which ultimately deprived them of the important outward manifestation of their authority. Similarly, the 1976 local government reforms chaired by Dasuki among others, excluded the traditional rulers from participating actively in political/security affairs. That is to say they were virtually excluded from a decision-making process of duly established local government council and were made non-executive, ceremonial as well as non-participatory in local government administration.

The reform among other things only provided for the establishment of traditional council of chiefs at the state and local government levels to handle chieftaincy and religious matters, assist in the maintenance of law and order and such other matters as the government might refer to the council from time to time. 
Consequently, the creation of traditional council of chiefs and their detachment from local government council emirates, marked the end of formal role of traditional rulers in politics and administration criminal justice system, security inclusive in Nigeria. Paradoxically, government had found it imperative to consult traditional rulers in order to establish their accountability and legitimacy in public eyes. Furthermore, they perceive traditional rulers not only as viable but also as an effective link particularly in implementing many of their programmes and policies that have direct bearing on the people of the grassroots level such as health, education, rural development, security etc.

It is because of these and other allowed roles played, the traditional rulers in recent times that successive governments considered them very vital to the efficient discharge of the former duty. Government all along regarded and accorded loyalty to them to the extent that they are at times consulted before making some key political appointments at both local, state and federal levels.

This can be more visible when the former regime of Babangida called on a meeting with Traditional rulers in Abuja admonishing them to use their position as traditional leaders of their various societies to solve the problem of insecurity in their areas.

From this we can infer that since the period of the Second Republic administration, the traditional rulers seemed to have been going back to their position they were during the first epoch of colonialist era. This is why Ademulekun has this to say:

When civilian politicians returned to power in October 1979 after 13 years of military interregnum, there was a brief return to the practice of forging an alliance with traditional rulers with the aim of winning mass support of their people or electorates. This alliance formation system eventually started as soon as the ban of partisan politics was lifted during the second half of 1979. But as was the case in 1960s those that emerged as ruling political leaders quickly, abandoned the idea of traditional rulers as allies and begin to treat them as subordinates.

However, the 1979 Constitution was short of the role of traditional institutions, because of the fear of proliferation of Emirs in the Caliphate and ethnic differences necessitated the dissolving of House of Chiefs. The Constitution also gives limited power to traditional institutions to have certain roles in the political system for each state to have a council of chiefs. They were to give advice to government on customary affairs of their own societies. There was also the needed collaboration with the law enforcement agencies for the maintenance of public order within their own territories.

Similarly, on matters with which the Governor may desire with this provision, the traditional rulers are more or less playing the role of executors and legislators of public programmes and policies. It was as a result of these changes whereby the traditional rulers are replaced by policemen and soldiers, that the Dasuki Committee on Local Government Reforms recommended the return of feudal system of traditional rulers and inclusion of them into local government administration. Notwithstanding, the report was heavily criticized by some traditional rulers, notably the Emir of Ilorin. Thus, everyone seems to feel that something needs to be done about the present debate of this institution, but no one seemed to be doing anything positively. The issue of traditional rulers since independence has not received any serious national attention. This resulted in questioning as to what then we shall do with the traditional administration in our contemporary security situation that in the burning debate of Constituent Assembly of 1977-1978 the institution was seriously attacked and challenged by popular democratic forces. In this vein, Malami (1987) from Sokoto argued that:

... let us not imagine that the future will be crisis and problems free. Therefore, every institution that can contribute to stability and speedy resolution of dispute and crisis must be preserved over the years whether be it under British colonial rule. Civilian rule after independence or even under military with the strong weapon of conquering at its disposal, traditional rulers have been called upon and used to stabilize crisis situations. However, the specter of crisis in Nigeria did not frighten most members of the Assembly into conceding at least an important role for this institution in its public continuity in the country.

Hence they were not favoured as before and have no specific role to play in security administration in Nigeria other than advice which was subject to acceptance and rejection by the government. The traditional rulers have no specific roles to play today, tomorrow or in the future. This is what led the Shehu of Borno into conceding that the traditional rulers were used by government as fire brigade mechanism only useful when there is a crisis in the country. 


\section{What Real Roles?}

$>$ Prestigious but ceremonial cooperational support in security maintenance surveillance.

D Increasing participatory role of Traditional Rulers in their local community security administration.

$>$ Link between the people and criminal justice.

$>$ Return to Traditional Rulers authority in Nigeria pertaining security Administration in Nigeria.

> Partial return of instrument of coercion (the police, courts, prison) with minimal control.

$>$ Inclusion of Traditional Rulers' participation in security affairs in their localities.

$>$ Creation of Traditional Council of Chiefs and attachment to Local Government to participate in the administration of security matters in Nigeria.

$>$ Consultation with Traditional Rulers to provide viable means of curtly insecurity in Nigeria.

\section{CONCLUSION AND WAY FORWARD}

It has been pointed out the views advanced as to whether Traditional Rulers should play a definite constitutional role in the contemporary security equation in Nigeria, the respect and loyalty being accorded to them by their respective communities who constitute a very large segment of the non-elites still raise the question of their usefulness and the meaningful roles they should play in security administration in Nigeria. Their supremacy is still being revered because of the failure of Local Government system which is supposed to replace them. The system is infested with corruption. That is the people are turning to traditional system at the chagrin of local Government system.

The traditional rulers were just a reincarnation or continuation from colonial selection, function with some modifications through post colonialism in Nigeria. The Traditional Institution is losing its authority in the discharge of their responsibilities/obligations as re-echoed in the Lord Lugard speech.

\section{REFERENCES}

[1] Abdullahi, S.A. (2005), Youth Deviance and Traditional Authority in Kano Metropolitan: Some Issues in Chieftaincy and Security in Nigeria $40^{\text {th }}$ Anniversary of the Emirship of HRH; Alhaji (Dr.), Ado Bayero.

[2] AbdulQadir, U.A., (2014), The Role of Traditional Rulers and the Islamic Religious Leaders in Sensitization and Mobilization of the Community on Election and Permanent Voter Participation and Modalities, Paper Presented at a Two-Day Sensitization Workshop for Traditional Rulers and Religious Leaders on Voter Registration and (Permanent) Voter Cards Exercise, Organized by the Ministry for Social Duties, Sokoto State Held at Giginya Hotel, Sokoto-Nigeria, 19 ${ }^{\text {th }}$ March, 2014.

[3] Ahmed, I.B., (2012), Intrinsic Human Relations Enhances Effective Security, Life and Property. An Article in Zabi da Tsari Column of Muryar Arewa (Voice of the North Magazine of July, 2012, 2013), The Need to Remedy Nigeria's Security Problems Through Emergency Measures Zabi da Tsari (Content Display) Column of Muryar Arewa (Voice of the North) Magazine of $28^{\text {th }}$ February, 2013: p53.

[4] Alemika, E.E.O. (1993); "Criminology, Criminal Justice and Philosophy of Policing in Nigeria", In T. N. Tamuno, I.L. Bashir, E.E.O. Alemika and A. O. Akano, (eds.) Policing Nigeria: Past, Present and Future, Lagos: Malthouse Press.

[5] Alemika, E.E.O. (2015), Security Crisis and Nigerian University System, being a Paper Presented at a Seminar on Security Crisis in Nigerian Universities held at the Main Auditorium University of Jos Main Campus, Jos, Plateau State-Nigeria.

[6] Baba, T.A.M., (2012), Security as a Basic Human Needs in Society, Being Keynote Address Delivered at a Workshop on Contemporary Security Challenges the Need for Awareness and Consciousness by Local Government Policy Makers, Organised by Prime Partners Held at Sokoto Guest Inn, Sokoto Nigeria, on July 24.

[7] Lugard, F. (1903), Second Address by the High Commission to the Sultan, Waziri and Elders of Sokoto, in Colonial Reports, Annual Northern Nigeria, 1900 - 1911.

[8] Malami, A.S., (2011), Role of Traditional Rulers in the development of Nigeria, Lecture Delivered at the Army Command and Staff College, August 2, 1978, Published in Sunday Trust, February 27, 2011.

[9] Maslow, A. H. (1943). A Theory of Human Motivation. Psychological Review, 50(4), 370-96.

[10] Nigerian Universities System, "Being a Paper Presented at a Seminar on Security Crisis in Nigerian Universities held at the Main Auditorium University of Jos Main Campus, Jos-Plateau State-Nigeria.

[11] Nweke, K., (2012), 'The Role of Traditional Institutions of Governance in Managing Social Conflicts in Nigeria's Oil-Rich Niger Delta Communities: Imperatives of Peace Building Process in the Post-Amnesty Era', British Journal of Arts and Social Sciences (5):2.

[12] Orji, K. E. \& Olali, S.T., (2010), 'Traditional Institution and their Dwindling Roles in Contemporary Nigeria: The River State Example', in T. Babawale, A. Aloa, \& B. Adesoji, The Chieftaincy Institutions in Nigeria, Lagos: Concept Publication Limted. 
[13] Radda, S.I. (2000), 'Methods of Maintenance of Internal Security in Kano', Being a Seminar Paper Delivered at Kano, $1^{\text {st }}-3^{\text {rd }}$ August, 2000.

[14] Tibendarana, P. K. (1976). The administration of Sokoto, Gwandu and Argungu under the Bristish: 19001946 AD. Unpublished Ph.D Dissertation, University of Ibadan. 